\title{
HUBUNGAN KELIMPAHAN EPIFAUNA DENGAN TINGKAT KERAPATAN LAMUN YANG BERBEDA DI PERAIRAN BANDENGAN JEPARA
}

\author{
The Relation of Abudance Epifauna with Different Seagrass Beds Density \\ in Bandengan Coastal Jepara
}

\section{Sonia Wulan, Siti Rudiyanti*), Bambang Sulardiono}

Program Studi Manajemen Sumberdaya Perairan, Departemen Sumberdaya Akuatik

Fakultas Perikanan dan Ilmu Kelautan, Universitas Diponegoro

J1. Prof. Soedarto, SH, Tembalang, Semarang, Jawa Tengah - 50275, Telp/Fax. +6224 7474698

Email : soniawulan37@yahoo.co.id

\begin{abstract}
ABSTRAK
Ekosistem padang lamun di Perairan Bandengan Jepara penting bagi biota akuatik khususnya epifauna. Kerapatan lamunakan mempengaruhi bahan organik yang digunakan oleh epifauna, selain itu kerapatan lamun juga dapat mengendapkan bahan organik yang akan mempengaruhi kelimpahan epifauna. Penelitian dilakukan pada bulan Maret 2016 di Perairan Bandengan yang bertujuan untuk mengetahui hubungan antara kelimpahan epifauna dengan kerapatan lamun yang berbeda di Perairan Bandengan Jepara serta hubungan antara kandungan bahan organik dengan tingkat kerapatan lamun di Perairan Bandengan Jepara. Metode penelitian yang digunakan yaitu pendekatan survei dengan metode sampling yaitu Purposive Random sampling. Hasil penelitian menunjukkan terdapat 1 jenis lamun yang ditemukan di Pantai Bandengan yaitu Thalassia sp. dengan kerapatan pada stasiun jarang (A) $178 \mathrm{ind} / \mathrm{m}^{2}$, stasiun padat (B) $368 \mathrm{ind} / \mathrm{m}^{2}$. Kelimpahan epifauna di kerapatan jarang dan padat di Perairan bandengan $140 \mathrm{ind} / 3 \mathrm{~m}^{2}$, dan $91 \mathrm{ind} / 3 \mathrm{~m}^{2}$. Rerata kandungan bahan organik sedimen pada kerapatan jarang, dan padat berturut-turut adalah $12.86 \%$ dan $76.85 \%$.Berdasarkan hasil uji regresi menunjukkan antara kelimpahan epifauna dengan tingkat kerapatan lamun menunjukkan hubungan tidak searah, setiap kenaikkan kerapatan lamun tidak diikuti oleh kenaikkan kelimpahan epifauna, serta tingkat kerapatan lamun dengan bahan organik terdapat korelasi yang kuat, semakin tinggi tingkat kerapatan lamun akan diikuti oleh bahan organik.
\end{abstract}

Kata Kunci; Perairan Bandengan; Kerapatan Lamun; Kelimpahan Epifauna; Bahan Organik.

\begin{abstract}
Seagrass ecosystem in Bandengan coastal Jepara is important for epifauna. Different seagrass density will affect levels of organic matter used epifauna, in addition the density of seagrass can also precipitate organic particles which affect the abundance of epifauna. This research was conducted on March 2016. The aimed of this research was to determine the relationship of epifauna's abundance to density seagrass and the relationship of organic matter to the density of seagrass. This research used survey method and random sampling technique. Samples were taken from three different station there are $(A)$ sparse density, and $(B)$ dense density. Sample epifauna were taken once a week for three time. The results showed only 1 type of seagrass found in Bandengan coastal Jepara that is Thalassia sp. With density on sparse station (A) $178 \mathrm{ind} / \mathrm{m}^{2}$, dense station 368 ind $/ \mathrm{m}^{2}$. The abundance of epifauna on station sparse (A) $140 \mathrm{ind} / 3 \mathrm{~m}^{2}$, dense station (B) $91 \mathrm{ind} / 3 \mathrm{~m}^{2}$, The highest abundance Sconsia sp $52 \mathrm{ind} / \mathrm{m}^{2}$ dan $28 \mathrm{ind} / \mathrm{m}^{2}$ and Cerithium sp $34 \mathrm{ind} / \mathrm{m}^{2}$ dan $19 \mathrm{ind} / \mathrm{m}^{2}$ Organic material content of sedimen on density was sparse and dense was $5.71 \%, 9.81 \%$. Based on the result of the correlation show that between the abundance of epifauna with seagrass density level there is a relation undirectional, density of seagrass will not increase accordingly to the abundance of epifauna, as well as to the content of organic matter. There is a close correlation that higher of density of seagrass will be followed by organic matter.
\end{abstract}

Key Word; Coastal of Bandengan; Seagrass Beds Density; Abundance of Epifauna; Organic matter

*) Penulis Penanggung Jawab 


\section{PENDAHULUAN}

Sumberdaya hayati yang dimiliki di Perairan Jepara meliputi ekosistem mangrove, ekosistem terumbu karang dan ekosistem padang lamun, ketiga ekosistem tersebut memiliki fungsi nilai, baik dilihat dari aspek ekologis maupun aspek ekonomis. Dalam kaitannya dengan sumberdaya hayati, ketiga ekosistem tersebut merupakan tempat mencari makan (feeding ground), tempat memijah (spawning ground) serta merupakan daerah asuhan (nursery ground) bagi berbagai biota laut yang berasosiasi.

Komunitas lamun memiliki fungsi ekologis yang penting di daerah pesisir.Struktur akar lamun yang rumit di dasar perairan membantu menstabilkan substrat dan mengurangi kekeruhan.Tegakan daun lamun yang rapat berperan penting untuk mengurangi energi gelombang, mengendapkan partikel organik dan nutrien serta menjadi tempat berlindung bagi berbagai jenis biota laut.

Epifauna merupakan biota benthos yang hidup pada permukaan substrat atau dasar laut (Ferianita, 2007).Epifauna yang hidup di lamun tersebut memanfaatkan lamun sebagai habitat dan juga memanfaatkan nutrien dari serasah lamun sebagai makanannya, dengan demikian epifauna memiliki hubungan atau asosisasi dengan lamun sebagai tempat berlindung, mencari makan, dan bertumbuh kembang.

Sumber bahan organik pada sedimen adalah lamun dan tinja biota bentik. Gangguan lingkungan di daerah pesisir akan mempengaruhi secara langsung organisme-organisme yang menjadi sumber bahan organik dalam sedimen tersebut (Knox, 2001). Kerusakan yang terjadi pada ekosistem lamun secara tidak langsung akan mempengaruhi kandungan bahan organik sedimen dan akan mempengaruhi kelimpahan epifauna yang hidup di daerah tersebut.

Tujuan dilakukannya penelitian ini adalah untuk mengetahui jenis lamun dengan kerapatan yang berbeda di Perairan Bandengan, Jepara, kelimpahan epifauna di substrat dasar di Perairan Bandengan, Jepara, bagaimana hubungan kelimpahan epifauna di substrat dasar dengan kerapatan lamun yang berbeda di Perairan Bandengan, Jepara dan bagaimana hubungan kerapatan lamun dengan bahan organik di Perairan Bandengan Jepara.Penelitian ini dilaksanakan pada Bulan Maret 2016 di Perairan Bandengan Jepara.Hasil dari penilitian ini diharapkan dapat memberikan informasi mengenai kondisi perairan Bandengan, Jepara.Informasi yang diperoleh semoga dapat bermanfaat bagi pengelolaan, pengembangan, dan pemanfaatan sumberdaya pesisir dan sumberdaya perikanan.

\section{MATERI DAN METODE PENELITIAN}

\section{Materi Penelitian}

Materi yang digunakan dan dikaji dalam penelitian ini adalah epifauna dan lamun serta kandungan bahan organik substrat ekosistem lamun di Perairan Bandengan Jepara dan parameter lingkungan perairan meliputi parameter fisika dan kimia.

\section{Metode Penelitian}

Metode yang digunakan dalam penelitian adalah metode penelitian dengan pendekatan survei, yaitu yang dilakukan berdasarkan data yang dipelajari dari data sampel yang diambil dari populasi, sehingga ditemukan kejadian-kejadian relatif, distributif, dan hubungan-hubungan antar variabel (Sugiyono, 2001 dalam Prakoso et $a l$; 2015).Metode pendekatan survei ini bersifat deskriptif karena penelitian ini juga membahas variabel-variabel lain yang berhubungan dengan pemasalahan berikut diuraikan faktor-faktor yang mempengaruhinya (Gulo, 2005 dalam Prakoso et al; 2015).

\section{Penentuan Lokasi dan Pengambilan Sampel}

Penentuan lokasi pengambilan sampel dilakukan setelah melakukan pengamatan langsung dan survei di lapangan.Penentuan lokasi sampling berdasarkan kebutuhan dan dapat mewakili wilayah penelitian secara keseluruhan. Metode pengambilan sampel menggunkan metode Purposive Random Sampling, Pengambilan sampel dilakukan pada 2 stasiun yang berbeda yaitu stasiun (A) pada bagian dengan kerapatan lamun jarang, stasiun (B) kerapatan lamun padat.

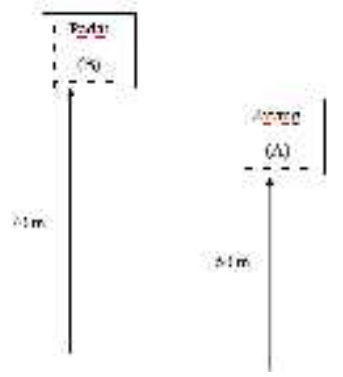

Pengukuran kerapatan lamun dilakukan dengan melakukan pemetaan dengan menggunakan garis transek tegak lurus garis pantai. Daerah padang lamun tersebut kemudian ditetapkan menjadi 2 stasiun sejajar garis pantai dengan kerapatan yang berbeda yaitu jarang dan padat dengan jarak antar stasiun 20 meter. Metode 
pengukuran yang digunakan untuk mengetahui kondisi padang lamun adalah metode transek dan petak contoh dengan bentuk kuadran berukuran $1 \mathrm{~m}$ x $1 \mathrm{~m}$. Metode sampling lamun yang digunakan adalah :

1. Sampling ini dilakukan pada lamun dengan kerapatan yang secara visual berbeda yaitu jarang dan padat, kemudian hasil pengamatan ini disajikan sebagai hasil jumlah pendahuluan yang akan dijadikan sebagai penentuan stasiun berdasarkan kerapatan yang berbeda.

2. Sampling dilakukan dengan menggunakan plot kuadran transek ukuran $1 \mathrm{~m} \times 1 \mathrm{~m}$ yang telah dibagi menjadi 16 sub petak.

3. Menghitung jumlah tegakan lamun di lokasi penelitian disamping itu, pengamatan juga dilakukan terhadap jenis-jenis lamun yang ada di lokasi tersebut.

4. Menentukan stasiun pengamatan berdasarkan kerapatannya yaitu, jarang, sedang dan padat berdasarkan pada penelitian sebelumnya. Menurut Widyorini et al. (2012) kriteria kerapatan lamun dapat dibagi menjadi 3, yaitu :

1. Kerapatan jarang $=106 \mathrm{ind} / \mathrm{m}^{2}$

2. Kerapatan padat $=355 \mathrm{ind} / \mathrm{m}^{2}$

Langkah-langkah pengambilan dan pengamatan epifauna di padang lamun adalah sebagai berikut :

1. Pengambilan epifauna berdasarkan 2 stasiun yang ditetapkan berdasarkan kerapatan lamun yang berbeda yaitu jarang dan padat dengan masing-masing stasiun dibatasi dengan kuadran $1 \mathrm{~m} \times 1 \mathrm{~m}$.

2. Sampel epifauna diambil di substrat dasar perairan pada kerapatan lamun yang berbeda yaitu jarang dan padat diambil secara langsung.

3. Pengulangan sebanyak 3 kali di setiap stasiun di titik yang telah ditentukan. Pengambilan sampel epifauna dilakukan satu minggu sekali selama 3 minggu.

4. Sampel epifauna yang telah didapatkan dimasukkan ke dalam botol sampel biota sesuai dengan lokasi ditemukannya. Sampel epifauna diberi formalin 4\% lalu dilakukan checklist dan identifikasi di laboratorium dengan melihat ukuran, bentuk, dan warna. Untuk identifikasi digunakan buku identifikasi (FAO Species Identiification Guide for Fishery Purpose) dan dari internet.

Pengujian bahan organik sedimen pada sampel tanah dianalisa dengan menggunakan metode gravimetrik berdasar dari BPAP (2014).Metode ini semua bahan organik dianggap volatile (menguap) bila dibakar pada suhu 550 0C selama 4 jam.Pengukuran parameter fisika-kimia yaitu kecerahan $(\mathrm{cm})$, kedalaman $(\mathrm{cm})$, kecepatan arus $(\mathrm{m} / \mathrm{s})$, salinitas menggunakan refaktometer, derajat keasaman/pH menggunakan kertas indikator $\mathrm{pH}$ serta oksigen terlarut menggunakan metode titrasi.

Analisis Data

Struktur Komunitas Epifauna

Kelimpahan relatif $(\mathbf{K R})$

Kelimpahan relatif adalah nilai antara kelimpahan individu tiap jenis dengan seluruh individu dalam suatu komunitas (Odum, 1971).

$$
\mathrm{KR}=\frac{n i}{N} \times 100 \%
$$

Keterangan :

KR : Kelimpahan relatif

ni : Jumlah individu spesies ke-i

$\mathrm{N}$ : Jumlah individu seluruh spesies

\section{Indeks keanekaragaman dan indeks keseragaman}

Keanekaragaman jenis merupakan suatu karakteristik tingkatan komunitas berdasarkan organisasi biologinya, dan akan menyatakan struktur komunitasnya. Keanekaragaman dapat dihitung dengan menggunakan Indeks Shannon-Wiener (Odum 1971):

$$
\underset{i=1}{\mathrm{~S}} \mathrm{H}^{\prime}=-\sum \mathrm{Pi} \ln \mathrm{Pi} ; \mathrm{Pi}=\mathrm{ni} / \mathrm{N}
$$

Keterangan:

$\mathrm{H}^{\prime}$ : Indeks keanekaragaman jenis

$\mathrm{Pi}:$ ni/N (Proporsi spesies ke-i)

ni : Jumlah individu jenis

$\mathrm{N}$ : Jumlah total individu

Kriteria yang digunakan untuk menggambarkan keanekaragaman Shannon-Wiener yaitu :

$\mathrm{H}^{\prime}=<1$, keanekaragaman rendah

$\mathrm{H}^{`}=1-3$, keanekaragaman tergolong sedang

$\mathrm{H}^{\prime}=>3$, keanekaragaman tergolong tinggi

Indeks keseragaman organisme makrozoobentos dihitung dengan menggunakan rumus Evennes Indeks (Odum 1993):

$$
\mathrm{e}=\mathrm{H}^{\prime} / \mathrm{LnS}
$$

\footnotetext{
${ }^{\text {C }}$ Copyright by Management of Aquatic Resources (MAQUARES)
} 
Keterangan:

$\mathrm{E}=$ Indeks keseragaman jenis

$\mathrm{H}^{\prime}=$ Indeks keaneka ragaman jenis

$\mathrm{S}=$ Jumlah jenis organisme

Hubungan Kelimpahan Epifauna dengan Tingkat Kerapatan Lamun dan Hubungan Tingkat Kerapatan Lamun dengan Bahan Organik

Hubungan kelimpahan epifauna dengan tingkat kerapata lamun dianalisis menggunakan analisa regresi dan korelasi.Regresi yang digunakan dalam penelitian ini adalah regresi linier sederhana dimana variabel yang terlibat di dalamnya hanya dua, yaitu variabel terikat Y (Kerapatan Lamun) dan variabel bebas X (Kelimpahan Epifauna) serta berpangkat satu. Bentuk persamaannya adalah:

Keterangan :

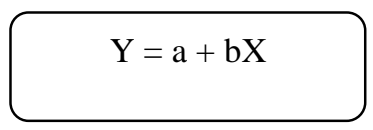

$\mathrm{Y}=$ variabel terikat (variabel yang diduga)

$\mathrm{X}=$ variabel bebas

$\mathrm{A}=$ intersep

$\mathrm{B}=$ koefien regresi (slop)

\section{HASIL DAN PEMBAHASAN}

Hasil

Deskripsi Lokasi Penelitian

Perairan Bandengan merupakan salah satu pantai di pesisir utara Jawa (pantura) yang terletak di utara Kabupaten Jepara, Jawa Tengah pada geografis $110^{\circ} 9^{\prime}$ 48, 02" sampai $110^{\circ}$ 58' 37,40" Bujur Timur, $5^{\circ} 43^{\prime}$ 20,67" sampai 6 $6^{\circ} 47^{\prime}$ 25,83" Lintang Selatan. Luas wilayah daratan Kabupaten Jepara 1.004,189 km² dengan panjang garis pantai $72 \mathrm{~km}$.

Lokasi penelitian dilakukan di daerah padang lamun yan terletak di bagian tmur dari pantai bandengan dengan membagi daerah tersebut menjadi 2 stasiun yaitu stasiun kerapatan padat (A) yang secara geografis terletak pada titik koordinat $06^{\circ} 32^{\prime} 58^{\prime}$ '. '1' LS dan $110^{\circ} 39^{\prime} 14^{\prime}$ '.4' BT, dan kerapatan padat (B) terletak pada titik koordinat $06^{\circ} 32^{\prime} 57^{\prime \prime} .1$ ' LS dan $110^{\circ} 39^{\prime} 14^{\prime \prime} .4^{\prime}$ BT.

Kerapatan Lamun

Jenis lamun yang diperoleh di daerah penelitian Perairan Bandengan Jepara adalah lamun jenis Thalassia sp. Berikut table kerapatan lamun Thalassia sp yang diperoleh di lokasi penelitian.

Tabel 1. Kerapatan Lamun Thalassia sp. Di Perairan Bandengan Jepara

\begin{tabular}{|c|c|c|c|c|}
\hline \multirow[b]{3}{*}{ Jenis } & \multicolumn{4}{|c|}{ Kerapatan } \\
\hline & \multicolumn{2}{|c|}{ Jarang (A) } & \multicolumn{2}{|c|}{ Padat (B) } \\
\hline & $\begin{array}{c}\mathrm{Ni} \\
\text { ind } / \mathrm{m}^{2}\end{array}$ & $\begin{array}{l}\text { KR } \\
(\%)\end{array}$ & $\begin{array}{c}\mathrm{Ni} \\
\text { ind } / \mathrm{m}^{2}\end{array}$ & $\begin{array}{l}\text { KR } \\
(\%)\end{array}$ \\
\hline Thalassia sp. & 178 & $100 \%$ & 368 & $100 \%$ \\
\hline Total $\left(\mathrm{ind} / \mathrm{m}^{2}\right.$ ) & 178 & $100 \%$ & 368 & $100 \%$ \\
\hline
\end{tabular}

Keterangan :

$\mathrm{Ni}=$ Jumlah individu dalam spesies $\quad \mathrm{KR}=$ Kelimpahan relatif

Keanekaragamn dan Keseragaman Epifauna di Substrat Dasar Perairan Bandengan, Jepara

Keanekaragam dan Keseragaman Epifauna yang didapatkan di Perairan Bandengan Kabupaten Jepara selama penelitian tersaji dalam tabel 2 sebagai berikut.

\begin{tabular}{|c|c|c|c|c|c|}
\hline \multirow{3}{*}{ No. } & \multirow{3}{*}{ Jenis } & \multicolumn{4}{|c|}{ Kerapatan Lamun } \\
\hline & & \multicolumn{2}{|c|}{ Jarang (A) } & \multicolumn{2}{|c|}{ Padat $(B)$} \\
\hline & & $\mathbf{N i}$ & KR $(\%)$ & $\mathbf{N i}$ & $\operatorname{KR}(\%)$ \\
\hline 1 & Sconsia sp & 52 & 37.14 & 28 & 30.77 \\
\hline 2 & Terebralia sp & 17 & 12.14 & 9 & 9.89 \\
\hline 3 & Rhinoclavis sp & 14 & 10 & 17 & 18.68 \\
\hline 4 & Turbo sp & 5 & 3.57 & 3 & 3.30 \\
\hline 5 & Vexillum sp & 3 & 2.14 & 3 & 3.30 \\
\hline 6 & Cymatium sp & 15 & 10.71 & 12 & 13.19 \\
\hline 7 & Cerethium sp & 34 & 24.29 & 19 & 20.88 \\
\hline
\end{tabular}




\begin{tabular}{ccccc}
\hline Total $\left(\right.$ ind $\left./ \mathrm{m}^{2}\right)$ & 140 & \multicolumn{1}{c}{100} & 91 & 100 \\
\hline Jumlah spesies & 6 & 7 \\
\hline H' & 1,51 & 1,69 \\
E & 0,84 & 0,87
\end{tabular}

\section{Kandungan Bahan Organik}

Kandungan bahan organik sedimen yang didapatkan di Perairan Bandengan Kabupaten Jepara selama penelitian tersaji dalam tabel 2 sebagai berikut.

Tabel 3. Kandungan bahan organik di Pantai Bandengan Jepara

\begin{tabular}{ccc}
\multirow{2}{*}{ Sampling Ke- } & \multicolumn{2}{c}{$\begin{array}{c}\text { Kandungan Bahan Organik Sedimen pada } \\
\text { Kerapatan Lamun }\end{array}$} \\
\cline { 2 - 3 } 1 & Padat $(\%)$ & Jarang(\%) \\
2 & 10.00 & 5.71 \\
3 & 9.14 & 4.86 \\
Rata - rata & 10.29 & 6.57 \\
\hline
\end{tabular}

Berikut bentuk histogram dari jumlah individu tegakan lamun yang ada di perairan Pantai Bandengan Jepara tersaji pada gambar 1.

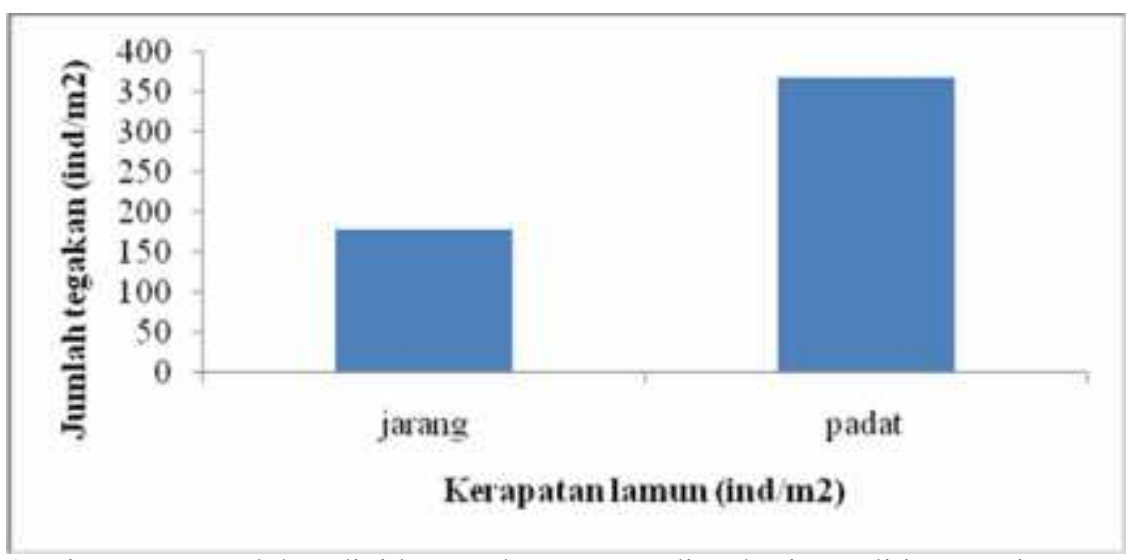

Gambar 1. Histogram Jumlah Individu Tegakan Lamun di Lokasi Penelitian Perairan Bandengan gambar 2.

Berikut bentuk histogram dari kelimpahan epifauna yang ada di perairan Bandengan Jepara tersaji pada

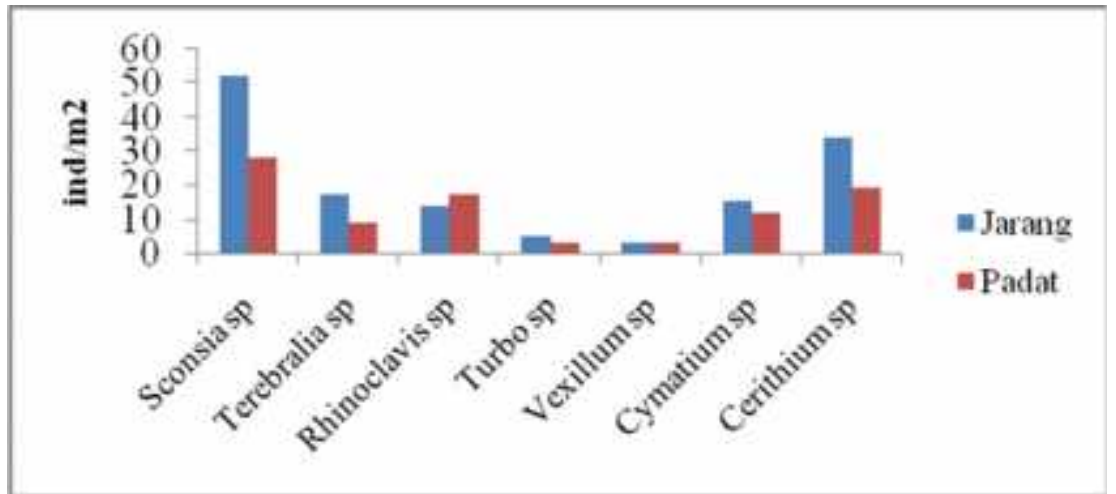

Gambar 2. Histogram Kelimpahan Epifauna di Perairan bandengan Jepara

\section{Parameter Lingkungan}

Parameter fisika kimia lingkungan yang didapatkan di Pantai Bandengan Kabupaten Jepara selama penelitian tersaji dalam tabel 4 sebagai berikut: 
Tabel 4. Parameter Fisika-Kimia

\begin{tabular}{|c|c|c|c|}
\hline \multirow{2}{*}{ Parameter } & \multicolumn{2}{|c|}{ Kisaran Hasil } & \multirow[t]{2}{*}{ Pustaka } \\
\hline & $\mathbf{A}$ & B & \\
\hline Suhu Air (cm) & $30^{\circ} \mathrm{C}$ & $30^{\circ} \mathrm{C}$ & $20-30^{\circ} \mathrm{C}$ (Effendi, 2003) \\
\hline Kedalaman $(\mathrm{cm})$ & $77 \mathrm{~cm}$ & $72 \mathrm{~cm}$ & $13 \mathrm{~m}$ (Kordi, 2011) \\
\hline Kecerahan $(\mathrm{cm})$ & sampai dasar & Sampai dasar & Sampai dasar (Effendi, 2003) \\
\hline Kec. Arus (m/s) & $0,034 \mathrm{~m} / \mathrm{s}$ & $0,09 \mathrm{~m} / \mathrm{s}$ & $0,25 \mathrm{~cm} / \operatorname{detik}($ Kordi, 2011) \\
\hline Substrat dasar & $\begin{array}{l}\text { Pasir, pecahan } \\
\text { karang }\end{array}$ & $\begin{array}{l}\text { Pasir, } \\
\text { karang }\end{array}$ & $\begin{array}{l}\text { Lumpur, pasir, kerikil, dan patahan } \\
\text { karang (Kordi, 2011) }\end{array}$ \\
\hline Salinitas $(\% o)$ & $33 \%$ & $33 \%$ & $25-35 \%$ \% (Dahuri, 2011) \\
\hline $\begin{array}{l}\text { Lanjutan Tabel } 4 . \\
\text { pH }\end{array}$ & 8 & 8 & 7 - 8,5 (Effendi, 2003) \\
\hline $\mathrm{DO}(\mathrm{mg} / \mathrm{l})$ & $7,2 \mathrm{mg} / 1$ & $7,2 \mathrm{mg} / 1$ & $12,4 \mathrm{mg} / \mathrm{l}$ (Effendi, 2003) \\
\hline
\end{tabular}

Hubungan antara Kelimpahan Epifauna dengan Tingkat Kerapatan Lamun di Perairan Bandengan Jepara

Hubungan antara kelimpahan epifauna di substrat dasar lamun dengan kerapatan lamun yang berbeda di Perairan Bandengan disajikan pada gambar 3 berikut:

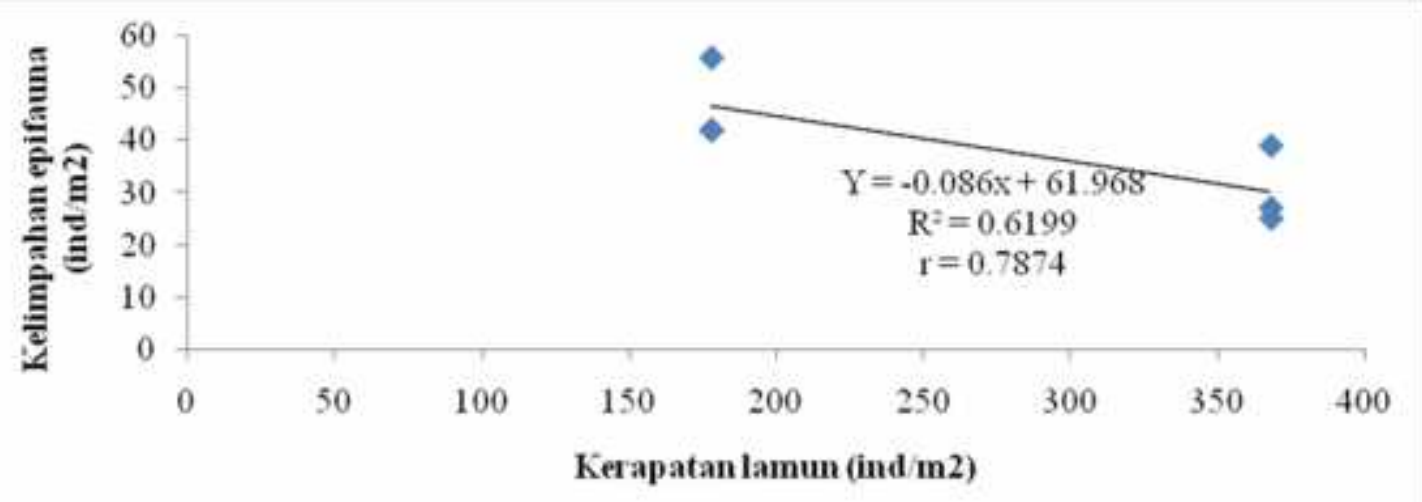

Gambar 3. Hubungan Kelimpahan Epifauna di Substrat Dasar Lamun dengan Tingkat Kerapatan Lamun di Perairan Bandengan

Hubungan antara Tingkat Kerapatan lamun dengan Bahan Organik di Perairan Bandengan, Jepara

Hubungan anatara kandungan bahan organik sedimen dengan kerapatan lamun yang berbeda di Perairan bandengan Jepara tersaji dalam gambar 4 berikut.

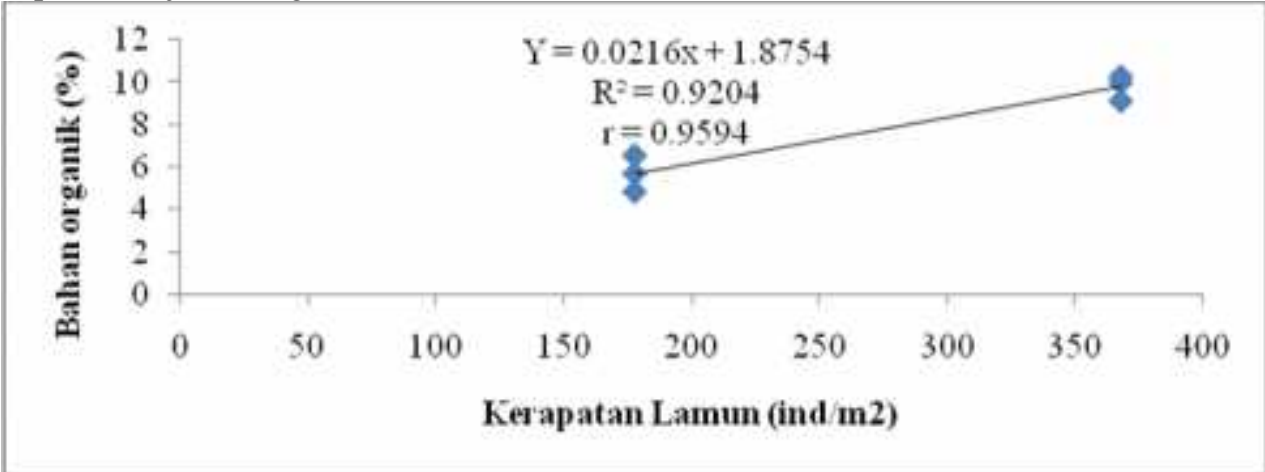

Gambar 4. Hubungan antara Kandungan Bahan Organik dengan Tingkat Kerapatan Lamun di Perairan Bandengan Jepara

\section{Pembahasan}

Berdasarkan hasil penelitian yang tersaji pada tabel 1, lamun yang ditemukan di Peraiaran Bandengan terdiri dari 1 jenis lamun yang merupakan famili Hydrocharitaceae yaitu spesies Thalassia sp. yang persebarannya merata dibagian utara Perairan Bandengan sehingga membentuk padang lamun. Jenis lamun Thalassia sp. ditemukan di semua stasiun berdasarkan kerapatan yang berbeda yaitu jarang, sedang, dan padat.

Lamun yang terdapat di sebelah utara Perairan Bandengan yaitu dari jenis Thalassia sp. Jenis lamun Thalassia sp. tumbuh di substrat berpasir dan pecahan karang karena di sebelah utara Perairan Bandengan bertipe substrat berpasir.Lamun jenis Thalassia sp. merupakan jenis paling banyak ditemui atau mendominasi

\footnotetext{
C Copyright by Management of Aquatic Resources (MAQUARES)
} 
pada lokasi penelitian di tiga kerapatan yang berbeda.Pada setiap stasiun dengan kerapatan yang berbeda yaitu jarang, dan padat jumlah individu jenis Thalassia sp. masing-masing berjumlah $178 \mathrm{ind} / \mathrm{m}^{2}$, dan $368 \mathrm{ind} / \mathrm{m}^{2}$. Hasil ini menunjukkan bahwa padang lamun di Perairan Bandengan hanya 1 jenis lamun yaitu Thalassia sp. yang mendominasi dari 2 kerapatan yang berbeda. Menurut Dahuri (2003), menyatakan bahwa lamun jenis Thalassia sp. termasuk spesies yang jumlahnya bisa berlimpah serta memiliki penyebaran luas. Hal ini disebabkan karena Thalassia sp. memiliki strategi adaptasi yang baik terhadap lingkungannya dimana tumbuhan ini memiliki perakaran serabut dengan mikrozoma akar aerobik sehingga mampu berkoloni lebih lebat di habitat dangkal dibandingkan dengan lamun jenis lainnya (Romimohtarto dan Juwana, 2001).

Hal ini karena padang lamun dapat membentuk vegetasi tunggal, tersusun atas satu jenis lamun yang tumbuh membentuk padang lebat, sedangkan vegetasi campuran terdiri dari $2-12$ jenis lamun yang tumbuh bersama-sama pada satu substrat. Spesies lamun yang biasanya tumbuh dengan vegetasi tunggal adalahThalassia hemprichii, Enhalus acoroides, Halophila ovalis, Halodule uninervis, Cymodocea serrulata, Thalassodendron ciliatum (Dahuri, 2003).

Hasil indeks keanekaragaman lamun di Perairan Bandengan di tiga kerapatan yang berbeda yaitu jarang, sedang, dan padat masing-masing sebesar 0.Menurut Odum (1971), bila $0<\mathrm{H}^{\prime} \leq 1$ maka keanekaragaman rendah, bila $1<\mathrm{H}^{\prime} \leq 2$ maka keanekaragaman sedang, sedangkan bila $\mathrm{H}^{\prime}>2$ maka keanekaragam tinggi.

Berdasarkan hasil nilai diatas keanekaragaman di tiga kerapatan yang berbeda termasuk dalam kategori rendah. Berdasarkan nilai indeks keanekaragaman tersebut kondisi lingkungan di lokasi penelitian tersebut dapat dikatakan kurang stabil, kurang stabilnya lingkungan di lokasi ini dikarenakan oleh kegiatan manusia di sekitar lokasi tersebut yaitu wisata karena di pantai tersebut ditemukan limbah dari kegiatan pariwisata seperti sampah plastik, serta kegiatan manusia seperti menjaring ikan atau biota laut lainnya, selain itu faktor pasang surut juga mempengaruhi kestabilan lingkungan, pada saat surut terendah hampir tidak tergenang oleh air. Hal ini diperkuat oleh oleh Nybakken (1988), menyatakan bahwa tumbuhan lamun hidup di perairan dangkal hingga pada kedalaman 50 - 60 meter bahkan mencapai 90 meter, namun melimpah di daerah pasang surut.

Berdasarkan tabel 3 epifauna yang ditemukan di substrat dasar dari hasil 3 kali sampling diperoleh 140 ind $/ 3 \mathrm{~m}^{2}$ di kerapatan jarang, dan $91 \mathrm{ind} / 3 \mathrm{~m}^{2}$ dikerapatan padat yang terdiri dari 7 spesies. Epifauna yang paling banyak ditemukan di substrat dasar adalah jenis Sconsia sp. dan Cerithium sp. yang mana epifauna ditemukan di substrat dasar yaitu pasir dan pecahan karang serta di daun lamun.Kehadiran yang melimpah pada suatu lokasi mencerminkan kelayakan tempat tersebut untuk kehidupan jenis tertentu dan secara ekologis sangat mendukung kehidupan biota akuatik lainnya.Hal ini diperkuat oleh Nybakken (1992) dalam Palin (2014), menyatakan bahwa Kelas Gastropoda merupakan organisme makrozoobentos kedua yang paling sering ditemukan.Hal ini dikarenakan kelas Gastropoda memiliki kemampuan adaptasi yang cukup baik terhadap lingkungannya. Pada kelas Gastropoda terdapat kulit kedap air yang berfungsi sebagai pembatas, banyak diantaranya yang bernafas melalui udara dan memakan plankton dan bahan organik. Gastropoda memiliki operkulum yang menutup rapat celah cangkang, ketika pasang turun mereka masuk dalam cangkang lalu menutup rapat celah menggunakan operkulum sehingga kekurangan air dapat diatasi.

Nilai indeks keanekaragaman (H') epifauna di substrat dasar pada kerapatan jarang 1,51 ; kerapatan sedang 1,69 ; dan kerapatan padat 1,69. Menurut Odum (1971), bila $0<\mathrm{H}^{\prime} \leq 1$ maka keanekaragaman rendah, bila $1<\mathrm{H}^{\prime} \leq 2$ maka keanekaragaman sedang, sedangkan bila $\mathrm{H}^{\prime}>2$ keanekaragaman tinggi.Berdasarkan nilai keanekaraman epifauna di substrat dasar di tiga kerapatan tersebut lebih dari 1 yang berarti keanekaragaman epifauna di tiga kerapatan tersebut dalam kondisi yang sedang.Indeks keanekaragamn dapat diartikan sebagai pernyataan yang sistematis melukiskan struktur komunitas sehingga mempermudah menganalisa informasi tentang jumlah dan macam organisme (Wilhm dan Dorris, 1968).

Hasil nilai indeks keseragaman (e) epifauna di substrat dasar lamun pada kerapatan jarang 0,84 dan kerapatan padat 0,87 . Nilai ini menunjukkan komposisi epifauna di substrat dasar di tiga kerapatan tersebut tidak menunjukkan adanya dominasi spesies, yang berarti penyebaran setiap jenis individu pada lokasi tersebut dikatakan merata.Hal ini diperkuat oleh Ruswahyuni (2008), bahwa semakin kecil indeks keseragaman maka semakin besar perbedaan jumlah antar spesies (adanya dominasi) dan semakin besar nilai indeks keseragaman maka semakin kecil perbedaan jumlah spesies sehingga kecenderungan dominasi oleh jenis tertentu tidak ada.

Hasil dari analisa bahan organik sedimen di substrat dasar lamun pada kerapatan jarang dengan rata-rata yaitu 5,71\%, dan kerapatan padat dengan rata-rata yaitu 9,81\%. Hal ini termasuk dalam kategori tinggi.Menurut Wood (1987) dalam Abdunnur (2002), menyatakan bahwa tinggi rendahnya kandungan bahan organik dalam sedimen berpengaruh besar terhadap populasi organisme dasar.Sedimen yang kaya bahan organik sering didukung oleh melimpahnya organisme bentik, termasuk juga epifauna karena bahan organik merupakan sumber makanan bagi biota laut yang hidup pada substrat dasar sehingga ketergatungannya terhadap bahan organik sangat besar.

Hubungan antara kelimpahan epifauna dengan tingkat kerapatan lamun menunjukkan nilai korelasi $\mathrm{r}$ dari hubungan kerapatan lamun dengan kelimpahan epifauna adalah 0.7874 artinya korelasi tinggi. Nilai determinan dari hubungan kerapatan lamun dengan kelimpahan epifauna adalah 0.6199 artinya kerapatan lamun berpengaruh terhadap kelimpahan epifauna sebesar 61,99\%.Hubungan antara kerapatan lamun dengan

C Copyright by Management of Aquatic Resources (MAQUARES) 
kelimpahan epifauna memiliki hubungan yang kuat.Nilai F hitung 6.5244 dan F tabel 4.052 yang artinya $\mathrm{H} 1$ diterima artinya ada hubungan antara kerapatan lamun dengan kelimpahan epifauna. Menurut Sugiyono (2007) pada rentang nilai $(r)=0,60-0,799$ termasuk dalam rentang hubungan yang kuat. Arah hubungan adalah negatif karena nilai (r) positif, artinya semakin tinggi kelimpahan epifauna maka akan tinggi pula kerapatan lamun, mengingat ekosistem lamun merupakan daerah untuk mencari makan, daerah asuhan dan daerah perlindungan bagi organisme bentik khususnya epifauna.

Hubungan antara kandungan bahan organik dengan kerapatan lamun yang berbeda menunjukkan nilai korelasi $\mathrm{r}$ dari hubungan bahan organik sedimen dengan tingkat kerapatan lamun adalah 0.9594 artinya korelasi sangat kuat.Nilai determinan dari hubungan antara kandungan bahan organik sedimen dengan tingkat kerapatan lamun di Perairan Bandengan Jepara adalah 0.9204 artinya kerapatan lamun terhadap bahan organik sebesar 92.04\%.Hubungan antara kandungan bahan organik dengan kerapatan lamun memiliki hubungan.Nilai F hitung 46.244 dan $\mathrm{F}$ tabel 4.052 yang artinya $\mathrm{H} 1$ diterima.Persamaan bernilai positif yaitu peningkatan kerapatan lamun diikuti oleh peningkatan bahan organik di Perairan Bandengan. Hal ini sesuai dengan pendapat Sugiyono (2007) pada rentang nilai $(r)=0,800-1,00$ termasuk dalam rentang hubungan yang sangat kuat.

\section{KESIMPULAN}

Kesimpulan yang didapat dari hasil penelitian ini adalah sebagai berikut:

1. Jenis lamun yang ditemukan di Perairan Bandengan yaitu Thalassia sp. Jenis lamun tersebut ditemukan di tingkat kerapatan yang berbeda yaitu jarang, dan padat.

2. Kelimpahan epifauna di substrat dasar lamun pada kerapatan jarang, dan padat di Perairan Bandengan yaitu $140 \mathrm{ind} / 3 \mathrm{~m}^{2}, 91 \mathrm{ind} / 3 \mathrm{~m}^{2}$.

3. Hubungan kelimpahan epifauna dengan kerapatan lamun bernilai linier negatif yang artinya setiap peningkatan jumlah kerapatan lamun maka tidak diikuti peningkatan jumlah kelimpahan epifaunadi Perairan Bandengan.

4. Hubungan tingkat kerapatan lamun dengan bahan organik bernilai linier positif yang artinya setiap peningkatan kerapatan lamun maka akan diikuti peningkatan bahan organik di Perairan Bandengan.

\section{UCAPAN TERIMAKASIH}

Penulis mengucapkan terimakasih kepada Dr. Ir. Pujiono W. Pernomo, MS; Dr. Ir. Djuwito, MS; Dra. Niniek Widyorini, MS sebagai dosen penguji yang telah memberikan saran dan membantu dalam perbaikan tugas akhir ini.

\section{DAFTAR PUSTAKA}

Abdunnur. 2002. Analisis Model Brocken Stick terhadap Distribusi Kelimpahan Spesies dan Ekotipologi Komunitas Makrozoobentos di Perairan Pesisir Tanjung Sembilan Kalimantan Timur. Jurnal Ilmiah Mahakam. 1(2): 77-88.

Dahuri, R. 2003. Keanekaragaman Hayati Laut dan Aset Pembangunan Berkelanjutan.PT. Gramedia Pustaka Utama. Jakarta.

Dirjen Perikanan Budidaya Air Payau. 2004. Pedoman Analisis Kualitas Air dan Tanah Sedimen, Jepara.

Effendi, Hefni. 2003. Telaah Kualitas Air Bagi Pengelolaan Sumberdaya dan Lingkungan Perairan. Kanisius. Yogyakarta.

[FAO] Food And Agriculture Organization. Species Identification Guide For Fishery Purpose. 2002. The Living Marine Resource of The Wastern Central Atlantic. USA (United State of America)

Ferianita, F. M. 2007. Metode Sampling Bioekologi. Bumi Aksara. Jakarta.

Knox, G.A. 2001. The Ecology of Seashores.CRC Press. London. 475 pp.

Kordi, H.K., Ghufron M. 2011. Ekosistem Lamun (SEAGRASS) Fungsi, Potensi dan pengelolaan. Rineka Cipta. Jakarta. 170 hal.

Nybakken, J.W. 1988. Biologi Laut, Suatu Pendekatan Ekologis. Gramedia. Jakarta.

Odum, P.E. 1971. Fundamentals of Ecology. W.B. Saunders Company: Philadelphia.

Palin, Rivaldy Sambo.2014. Pengaruh Struktur Komunitas lamun Terhadap Distribusi makrozoobentos di Pulau Balanglompo Kecamatan Mattiro Sompe Kabupaten Tangkep.Universitas hasanuddin.Makassar.

Prakoso, K., Supriharyono, Ruswahyuni. 2015. Kelimpahan Epifauna di Substrat Dasar dan Daun Lamun Dengan Kerapatan yang Berbeda di Pulau Pahawang Provinsi Lampung.Diponegoro Journal of Maquares. Vol 4 (3) : 11-122.

\footnotetext{
${ }^{\complement}$ Copyright by Management of Aquatic Resources (MAQUARES)
} 
Romimohtarto, K. dan S. Juwana.2001. Biologi Laut Ilmu Pengetahuan tentang Biota Laut. Djambatan: Jakarta.

Ruswahyuni.2008. Struktur Komunitas Makrozoobenthos yang Berpasir dengan lamun pada Pantai Berpasir di Jepara. Jurnal Saintek Perikanan. III (2) : 33-36.

Sugiyono. 2007. Metode Penelitian . CV. Alfabeta. Bandung.

Widyorini, N., Ruswahyuni., B. Sulardiono., D. Suprapto., dan A. Suryanto., 2012. Kajian Kondisi Ekosistem Pulau Panjang Untuk Kegiatan perikanan di kabupaten Jepara Provinsi Jawa Tengah. Laporan Hibah Penelitian FPIK Undip. Semarang.

Wilhm, J. L. And T. C. Dorris. 1968. Biological Parameter of Water Quality Criteria. Biology Scientific Publication. Oxford. England. 